\title{
RODÍZIO DAS FIRMAS DE AUDITORIA E O GERENCIAMENTO DE RESULTADOS NO BRASIL
}

\author{
AUDIT FIRM ROTATION AND EARNINGS MANAGEMENT IN BRAZIL
}

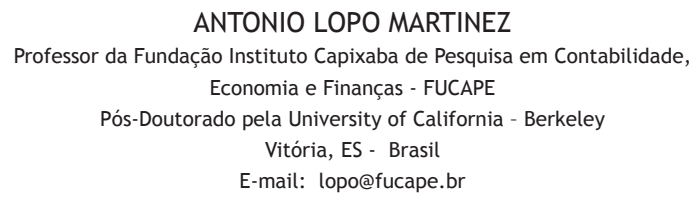

ANTONIO LOPO MARTINEZ

Professor da Fundação Instituto Capixaba de Pesquisa em Contabilidade, Economia e Finanças - FUCAPE

Pós-Doutorado pela University of California - Berkeley Vitória, ES - Brasil

E-mail: lopo@fucape.br

GRACIELA MENDES RIBEIRO REIS

Mestrado em Ciências Contábeis pela Universidade Federal da Bahia, UFBA Diretora da Pricewaterhousecoopers Auditores Independentes Salvador, BA - Brasil

E-mail: graciela.reis@br.pwc.com

\section{RESUMO}

O principal objetivo da implantação do rodízio de auditores independentes foi a preservação da independência e ética do auditor externo, e a conseqüente diminuição das fraudes e dos erros contábeis. Para investigar se o procedimento foi eficaz, através da análise de Companhias Abertas entre 1997 a 2007, com base na metodologia AWCA $\square$ Abnormal Working Capital Accruals, foi analisado os efeitos do gerenciamento de resultados decorrentes da troca da empresa de auditoria, enfocando-se, principalmente, o motivo da troca (rodízio obrigatório ou troca espontânea), classificação da empresa de auditoria em Big Four (PwC, DTT, E\&Y e KPMG), e o tempo de relacionamento da empresa de auditoria com a empresa auditada. Confirmou-se que com ou sem rodízio de auditores independentes os efeitos decorrentes do gerenciamento de resultado não apresentam diferença significativa na sua essência. Vale salientar que essas empresas de auditoria classificadas como as Big Four possuem práticas de rodízio de profissionais das equipes formalizadas em suas regras internas.

Palavras-chave: Rodízio de auditores independentes; Auditor Independente; Gerenciamento de resultado

\section{ABSTRACT}

The main reason for requiring rotation of independent auditors is to preserve independence and ethics in the relationship between the audited company and its external auditing firm and consequently to reduce accounting fraud and errors. To investigate whether this procedure was effective in Brazilian capital market, we analyzed data on Brazilian public companies between 1997 and 2007. We applied the abnormal working capital accruals (AWCA) method to analyze the effects on earnings management of changing the auditor, focusing on the reason for the change (obligatory or spontaneous), classification of the auditing firm among the Big Four (PWC, DTT, E\&Y and KPMG) and length of the relationship with the audited company. The findings indicate there is no significant effect on earnings management of changing the auditing firm. It can happen due to the fact that all of the Big Four have internal policies to rotate the staff assigned to specific audited companies.

Key words: Audit firm rotation, independent auditing, earnings management. 


\section{INTRODUCTION}

Article 31 of Instruction 308 from the Brazilian Securities Commission (CVM), issued in May 1999, establishes that the same independent auditor may not render services to a client for more than five consecutive years and at least three years must pass before re-contracting. According to the CVM, this rule was established to prevent an extended relationship between the auditor and the client firm from reducing the independence and objectivity of the auditing process.

However, there is a certain amount of controversy over: i) to what extent the independence of auditing firms is really impaired by a long-term relationship with the client; and ii) the desire to maintain that relationship. Another doubt is whether the potential benefits of changing auditors periodically are outweighed by the drawback of losing the specific knowledge obtained by the auditing firm during the relationship with the client.

To shed light on these matters, we investigate how the rotation has impacted the quality of accounting information disclosed to the market by Brazilian public companies. The aim of requiring auditor rotation is to preserve the independence and ethics of the relationship. Therefore, our basic research question is: does rotation of audit firms have an effect on earnings management?

We address this question by examining data on Brazilian public companies obtained from Economatica database covering the years from 1997 to 2007, excluding financial institutions, and information on the identity of the external auditor available at CVM website. The reason for excluding financial institutions is that besides the rules issued by CVM, they are also subject to specific rules issued by the Brazilian Central Bank, including the form for presenting their financial statements, giving them much less leeway to manage earnings.

We find that rotation of the auditing firm in Brazil does not have a significant effect on the propensity of listed Brazilian companies to manage earnings. This finding contributes to a better understanding of the effects of prolonged relationships between independent auditors and their clients.

The article is organized into six sections including this introduction. In the second section we present a brief review of the literature on independent auditors and their rotation, and in the third section we summarize the literature on earnings management. In the fourth we explain the methods applied to analyze the research question and in the fifth section we present the study results. The sixth section contains our concluding remarks.

\section{INDEPENDENT AUDITING AND ROTATION OF AUDITING FIRMS}

According to Becker (1998), auditing reduces information asymmetry between 
managers and the market, providing more credibility to firms' financial statements. According to Boynton, Johnson \& Kell (2002), shareholders rely on audited financial statements to have assurance that managers are running the company properly.

The emergence of large corporate organizations entails a separation between shareholders (owners) and managers, leading to agency conflicts resulting from a lack of alignment between the shareholders and the executives hired to manage the firm (Fama \& Jensen, 1983). The more dispersed the ownership structure is, the greater will be the chance of agency problems. Independent auditing is seen as one of the main mechanisms to reduce these agency costs (Jensen \& Meckling, 1976).

According to Arens, Elder \& Beasley (2002), independence is the bedrock of the auditing profession. The work of independent auditors would have little value if investors could not rely on opinions based not only on auditors' professional competence, but also on the impartiality their independence allows.

Various authors have stressed that mandatory rotation of auditing firms is important because long-running intimacy with the client can erode this necessary independence (Geirger \& Raghunandan, 2002).

From the standpoint of regulators, the periodic change of the auditing firm makes it more likely independent auditors will not yield to pressures from management, and will thus be able to maintain their diligence and commitment to independence and ethics in conducting their work.

In counterpoint to this position, auditing firms argue that such a requirement goes too far, because they already have internal rules to rotate the staff members in charge of auditing each client company. They further argue that the quality of auditing also depends on the expertise about the specific business segment and knowledge of the audited company built up over the years, to allow auditors to better define and evaluate the risks of irregularities that may be committed by the client company with respect to generally accepted accounting principles. Therefore, requiring periodic rotation of auditing firms can be counterproductive. This position is voiced by DeAngelo (1981) and Nelson, Elliott and Tarpley (2002).

Chew (2003) stressed that rules established to require auditor rotation are mainly a response to failures to detect irregularities in recent years in large corporations in countries like the United States and Australia. The debate over this issue became more intense in 2002 after the U.S. Congress approved the SarbanesOxley Act, according to which every five years auditing firms must rotate the lead and concurring partners assigned, to head up the audit of all companies with securities listed for trading on American exchanges. It also mandated the General Accounting Office to perform a detailed study on the question of auditor rotation, for the possible adoption of stricter rules calling for rotation of the auditing firm itself. At that time, some other countries already had such rules in place, such as Germany, where the Commercial Code establishes that companies listed on German bourses may not use the same auditor for more than six years in any ten-year period (GAO Report).

Other countries, such as Austria, Greece and Italy, also require auditor rotation. In Italy, it was determined by a law enacted in 1974, by which the auditing firm must 
be rotated every five years for listed companies.

The discussion over auditor rotation in the United States predates SarbanesOxley, though the various accounting scandals (particularly the spectacular implosion of Enron) that prompted the Act also heightened this debate. As mentioned, Congress balked at requiring rotation of the auditing firm itself, instead of ordering the General Accounting Office to conduct a detailed study of the international experience in this respect. The study's results were basically noncommittal, and so far stricter requirements have not been established (Raghunandan \& Rama, 2006).

One of the main advantages envisioned of rotating auditing firms is to prevent the development of an overly cozy relationship with the client. The belief is that auditing firms over time can start to lose their independence, even with rotation of the partners in charge of the audit, making them more likely to yield to pressures from managers to allow dodgy accounting practices to pass without criticism, or at least to soften this criticism, i.e., to examine the financial statements with rosecolored glasses instead of the necessary skeptical eye.

On the matter of rotating auditing firms instead of just partners, the position of the Australian Securities and Investments Commission (ASIC) is that "partner rotation, while useful during the life of an audit engagement, will not achieve the same result as firm rotation. It is not credible that one partner will seriously challenge the established audit practice and advice previously provided by his firm through another partner" (ASIC, 2002, p.5).

The view in Brazil is similar. The decision to require rotation of the auditing firm every five years was prompted by a series of scandals involving financial institutions in the 1990s, particularly those of Banco Econômico and Banco Nacional, which caused huge losses to the financial market and many accountholders (Oliveira \& Santos, 2007).

Each of these banks had longstanding relationships with its auditing firm, and in both cases the auditors had found nothing wrong with the banks' accounts despite massive irregularities that led to their liquidation. Instead of being highly profitable as depicted in their financial statements over the years, they had both been doctoring the books to hide huge losses on bad loans, in many cases given to related parties. To prevent further scandals, in 1996 the Brazilian Central Bank issued Resolution 2267, requiring rotation of auditing firms every four years for financial institutions. The Central Bank took this action to calm the markets by showing firm resolve in its oversight of the financial system.

Following the lead of Central Bank, in 1999 Brazilian Securities Commission (CVM) issued Instruction 308, establishing that all listed companies must engage a new auditing firm or individual auditor every five years, with a minimum three-year interval before rehiring. CVM based this decision on its belief that "the provision of auditing services to the same public company for a long period can jeopardize the quality of this service" (Assunção \& Carrasco, 2008).

Given the richness of literature on auditing, we narrow our discussions to the role audit firm rotation in earnings management. Some studies have examined the link 
between a change of auditors and earnings management (DeFond \& Subramanyam, 1998 and Davidson, Jiranporn \& DaDalt 2006). It was found that the auditor is more likely to detect material misstatements in the earlier years of the engagement, then such capability decreases gradually for the following twenty years of engagement (Piot and Janin, 2005. Davis et all, 2000). Recently, after the application of the Sarbanes Oxley Act 2002 (SOX) which imposed the rotation of auditor every five years, it was found that non GAAP earnings management practices have declined, an issue that reflects that when the auditor spends longer tenure with the client, he/ she would not allow their managing of their reported earnings practices (Davis et al, 2009). In Brazil, Azevedo \& Costa (2008) in preliminary study in this topic, could not infer the precise consequences of auditor changes in earnings management.

In this context, our basic research question is: Does rotation of audit firms have an effect on earnings management in Brazil? As a member of the World Trade Organization, Brazil is attracting more and more direct and financial investment from the international community. Additionally, the auditors 'role is a hot issue under debate in the US, UK and Continental European countries, thus the Brazilian experience may provide important lessons to the world.

\section{METHODOLOGICAL PROCEDURES}

We carried out a descriptive and exploratory analysis of the data, utilizing frequency distributions and statistical coefficients, represented through graphics and tables. We also formulated a panel data model, due to the structure of the database, containing time series and cross-sectional data.

Our sample consists of non-financial companies (i.e., excluding banks, insurers, pension fund operators etc.) listed on São Paulo Stock Exchange (BOVESPA) between 1997 and 2007. We obtained the companies' financial information from Economatica database and the information on the auditing firm from CVM database.

This method allowed us to classify the companies according to the auditing firm and follow the evolution of the financial variables over the studied period, for a total of eleven observations for each variable of each company.

To keep the sample uniform and consistent, we discarded any companies that for some reason did not have financial data or information on the auditor for the entire studied period. The final sample contained 88 companies, for a total of 968 observations.

The variables analyzed were the following:

- $\quad$ Earnings management, determined according to abnormal working capital accruals;

- $\quad$ Classification into companies audited or not by on of the Big Four (PwC, DTT, E\&Y and KPMG); 
- $\quad$ Change of auditor - whether there was a change in the auditing firm during the study period;

- $\quad$ Reason for changing auditing firm, whether this was because of the CVM's five-year limit or was spontaneous;

- $\quad$ Time of relationship with the auditing firm.

- $\quad$ Type of opinion (with or without reservation) - a reservation means there was at least one relevant aspect of the financial statements observed by the auditor that departed from generally accepted accounting principles or there was a relevant limitation in the scope of the auditing. In this respect, we classified adverse or negative opinions as having reservation.

To analyze earnings management, we used abnormal working capital accruals (AWCA), as it uses the working capital as proxy, measuring only the Discretionary Current Accruals. It is different from other models (Jones, 1991; Kang \& Sivaramakrishnan, 1999; Paulo, 2007), which are broader in scope as they measure discretionary current and non-current accruals. Note that the model's scope does not make it inferior or superior to others; rather, it is a question of being appropriate for the study's objectives or requirements.

Conceptually, the AWCA model measures the perceived difference between the working capital and a proxy of expectations on the amount of working capital needed to support the current sales levels. This difference represents a percentage of the rise in working capital, which does not sustain the current sales level (DeFond \& Park, 2001).

To determine the DCA, AWCA model uses the following variables, as described by Defond and Park (2001):

$$
A W C A_{t}=W C_{t}-\left[\left(W C_{t-1} / S_{t-1}\right) \times S_{t}\right] \quad \text { (Equation 1), in which: }
$$

- $\quad \mathrm{t}=$ year; thus $\mathrm{t}-1$ refers to the prior year;

- $\quad \mathrm{AWCA}_{\mathrm{t}}=$ abnormal working capital accruals in the current year;

- $\quad \mathrm{WC}_{\mathrm{t}}=$ noncash working capital in the current quarter computed as (current assets - cash and short-term investments) - (current liabilities - shortterm debt);

- $\quad \mathrm{WC}_{\mathrm{t}-1}=$ working capital in last year;

- $\quad \mathrm{S}_{\mathrm{t}}=$ sales in the current year; and

- $\mathrm{S}_{\mathrm{t}-1}=$ sales in year $\mathrm{t}-1$. 
The abnormal working capital accruals for the year are scaled by sales revenue in the same year. The empirical analysis of the earnings management focuses on the absolute value of discretionary accruals.

The panel data procedure combines in a single regression both the time series and cross-section analysis. The method of Da Silva assumes that the observed value of the dependent variable at the $t$-th time point and in the $i$-th cross-sectional unit can be expressed as follows:

$$
y_{i t}=\boldsymbol{x}_{i t}^{\prime} \mathrm{b}+a_{i}+b_{t}+e_{i t} \quad i=1, \ldots, N, t=1, \ldots, T \text { (Equation 2) }
$$

where:

$\boldsymbol{x}_{i t}^{\prime}=\left(x_{i t 1}, \ldots, x_{i t p}\right)$ is a vector or explanatory or predictive variables for the $\mathrm{t}$-th time point and i-th cross-sectional unit;

$\mathrm{b}=\left(\mathrm{b}_{1}, \ldots, \mathrm{b}_{p}\right)$ is a vector of unknown parameters;

$a_{i}$ is a time-invariant cross-sectional unit effect;

$b_{t}$ is a cross-sectionally invariant time effect; and

$e_{i t}$ is the random effect assumed for cross-sectional units that cannot be attributed to either the explanatory variables or to time.

We use the following matrix notation to represent the model:

$$
y=\boldsymbol{x} \mathbf{b}+\boldsymbol{u},
$$

where:

$\boldsymbol{u}=\left(\boldsymbol{a} \otimes \boldsymbol{1}_{T}\right)+\left(\boldsymbol{1}_{N} \otimes \boldsymbol{b}\right)+\boldsymbol{e}$, where $\mathbf{1}_{N}$ is an N $\times 1$ vector all of whose elements are equal to one and $\otimes$ denotes the Kronecker product;

$y=\left(y_{11}, \ldots, y_{1 T}, y_{21}, \ldots, y_{N T}\right)^{\prime} ;$

$X=\left(x_{11}, \ldots, x_{1 T}, x_{21}, \ldots, x_{N T}\right)^{\prime} ;$

$\mathbf{a}=\left(a_{1}, \ldots, a_{N}\right)^{\prime} ;$

$\boldsymbol{b}=\left(b_{1}, \ldots, b_{T}\right)^{\prime} ;$ and

$\mathbf{e}=\left(e_{11}, \ldots, e_{1 T}, e_{21}, \ldots, e_{N T}\right)^{\prime}$ 
The estimators of the regression parameters according to the method of Da Silva are obtained by generalized least squares (GLS). For more details, see Da Silva (1975) and Seely (1970).

\section{RESULTS}

Analyzing the earnings management variable we found there were 12 observations with extreme values, i.e., excessively large values in relation to the other observations in the data set, as shown in Table 1 below. In the years when these extreme values occurred, the independent auditors' reports all expressed no reservation. Besides, only one of the companies (Aço Altona) was audited by one of the Big Four (Ernest \& Young Auditores Independentes S.C.). In the years before and after the extreme value occurrence the auditor was the same, except for Bicicletas Caloi S.A., which changed the auditor in the year of the extreme value.

Table 1. Companies with extreme earnings management coefficients

\begin{tabular}{ccccc}
\hline \hline Audited Company & Independent Auditor & Year & Years of & $\begin{array}{c}\text { Earnings } \\
\text { Management }\end{array}$ \\
\hline Bicicletas Caloi S.A. & Trevisan Auditores Indep. & 2000 & 3 & 1.3427 \\
Bicicletas Caloi S.A. & Rodyo's Auditores Indep. S.S. & 2004 & 1 & 1.6465 \\
Bicicletas Caloi S.A. & Rodyo's Auditores Indep. S.S. & 2006 & 3 & 1.4667 \\
Bicicletas Caloi S.A. & Rodyo's Auditores Indep. S.S. & 2007 & 4 & 28.4936 \\
$\begin{array}{c}\text { Micheletto } \\
\text { Dhb Ind e Comercio }\end{array}$ & Imer Puerari \& Cia Auditores & 2006 & 3 & 1.0247 \\
S.A. & Imer Puerari \& Cia Auditores & 2006 & 3 & 1.0293 \\
Aço Altona & Ernest \& Young Auditores Indep. S.C. & 2002 & 5 & 2.3290 \\
Docas Investimentos & Units Auditores Indep. & 2001 & 3 & 1.7909 \\
S.A. & JPPS Auditores Indep. S.S. & 2007 & 2 & 8.3793 \\
B Duarte & Trevisan Auditores & 2002 & 4 & 1.0487 \\
Rectoy & DRS - Auditores & 2007 & 2 & 3.9129 \\
Vulcabrás & Etae- Auditores Indep. & 2000 & 3 & 2.3431 \\
\hline \hline
\end{tabular}

We performed a descriptive analysis with and without these outliers. The results showed that the earnings management coefficients of the companies were on average higher when analyzed with the extreme values. In terms of relative dispersion, the earnings management values were more dispersed when analyzed with outliers, as expected. The highest and lowest earnings management values were 28.4936 and 4.3773e-05, respectively, as shown in Table 2 . 
Table 2. Earnings management coefficients of companies with and without extreme observations, for the period from 1997 to 2007.

\begin{tabular}{cccccc}
\hline \hline & \multicolumn{4}{c}{ Earnings Management by Audited Companies } \\
\cline { 2 - 6 } & Mean & Median & Minimum & Standard Deviation \\
\hline $\begin{array}{c}\text { Without } \\
\text { Extreme Data }\end{array}$ & 0.0844 & 0.0466 & $4.3773 \mathrm{e}-05$ & 0.9169 & 0.1165 \\
$\begin{array}{c}\text { With Extreme } \\
\text { Data }\end{array}$ & 0.1400 & 0.0475 & $4.3773 \mathrm{e}-05$ & 28.4936 & 0.9766 \\
\hline \hline
\end{tabular}

Table 3 shows the results of the companies' earnings management coefficients according to the characteristics selected for the study. There was no significant difference in the conclusions with our without the extreme values in the data set. Therefore, to construct Figures 1 to 3 we removed the 12 outliers (presented in Table 1) with earnings management coefficients between 1 and 28.

Table 3. Earnings management with and without atypical data, according to the characteristics selected for study, in the period from 1997 to 2007.

\begin{tabular}{|c|c|c|c|c|c|}
\hline & \multicolumn{5}{|c|}{ Earnings Management of Audited Companies } \\
\hline & Mean & Median & $\begin{array}{l}\text { Standard } \\
\text { Deviation }\end{array}$ & Minimum & Maximum \\
\hline \multicolumn{6}{|l|}{ With Extreme Data } \\
\hline No Change of Auditor & 0.1528 & 0.0476 & 1.0969 & $4.38 \times 10^{-05}$ & 28.4936 \\
\hline Change of Auditor & 0.0922 & 0.0468 & 0.1543 & $3.10 \times 10^{-04}$ & 1.6465 \\
\hline By Obligatory Rotation & 0.1151 & 0.0637 & 0.2180 & 0.0003 & 1.6465 \\
\hline By Spontaneous Decision & 0.0822 & 0.0461 & 0.1159 & 0.0004 & 0.8734 \\
\hline \multicolumn{6}{|l|}{ Auditor's Opinion } \\
\hline Without Reservation & 0.1459 & 0.0459 & 1.0353 & $4.38 \times 10^{-05}$ & 28.4936 \\
\hline With Reservation & 0.0926 & 0.0586 & 0.1085 & $6.39 \times 10^{-04}$ & 0.6391 \\
\hline \multicolumn{6}{|l|}{ Classification of Auditor } \\
\hline Non-Big Tour & 0.2088 & 0.0575 & 1.3729 & $4.38 \times 10^{-05}$ & 28.4936 \\
\hline Big Four & 0.0715 & 0.0411 & 0.1370 & $5.63 \times 10^{-05}$ & 2.3290 \\
\hline \multicolumn{6}{|l|}{ Without Extreme Data } \\
\hline No Change of Auditor & 0.0844 & 0.0464 & 0.1185 & $4.38 \times 10^{-05}$ & 0.9169 \\
\hline Change of Auditor & 0.0846 & 0.0467 & 0.1093 & $3.10 \times 10^{-04}$ & 0.8734 \\
\hline By Obligatory Rotation & 0.0900 & 0.0635 & 0.0927 & 0.0003 & 0.4071 \\
\hline By Spontaneous Decision & 0.0822 & 0.0461 & 0.1159 & 0.0004 & 0.8734 \\
\hline \multicolumn{6}{|l|}{ Auditor’s Opinion } \\
\hline Without Reservation & 0.0834 & 0.0448 & 0.1175 & $4.38 \times 10^{-05}$ & 0.9169 \\
\hline With Reservation & 0.0926 & 0.0586 & 0.1085 & $6.39 \times 10^{-04}$ & 0.6391 \\
\hline \multicolumn{6}{|l|}{ Classification of Auditor } \\
\hline Non-Big Tour & 0.1025 & 0.0548 & 0.1358 & $4.38 \times 10^{-05}$ & 0.9169 \\
\hline Big Four & 0.0668 & 0.0411 & 0.0908 & $5.63 \times 10^{-05}$ & 0.7444 \\
\hline
\end{tabular}


Figures 1 to 3 are the graphics of the earnings management variable of the companies according to the characteristics chosen for the study, for the years from 1997 to 2007. The data reveal that the medians, means and standard deviations of the earnings management values were approximately equal irrespective of whether there was a change of auditor, as can be seen in Figure 1 and in Table 3.

The results also reveal that the median earnings management coefficient was slightly higher in years when there was a change in auditor because of mandatory rotation, as shown in Figure 2. Note that the average of the companies is higher when the auditor was not one of the Big Four (0.1025) than when it was (0.0668). Furthermore, the standard deviation of the companies audited by one of the Big Four is 0.0908 . However, this measure of variability is higher $(0.1358)$ for companies audited by a firm other than the Big Four. In other words, it can be said that the earnings management values are more dispersed for companies not audited by one of the Big Four, as also shown in Figure 3.

Finally, the descriptive and exploratory analyses of the data show there does not appear to be a relationship between earnings management and the variables analyzed so far, except between the earnings management variables and the classification of type of auditor (Big Four or not).

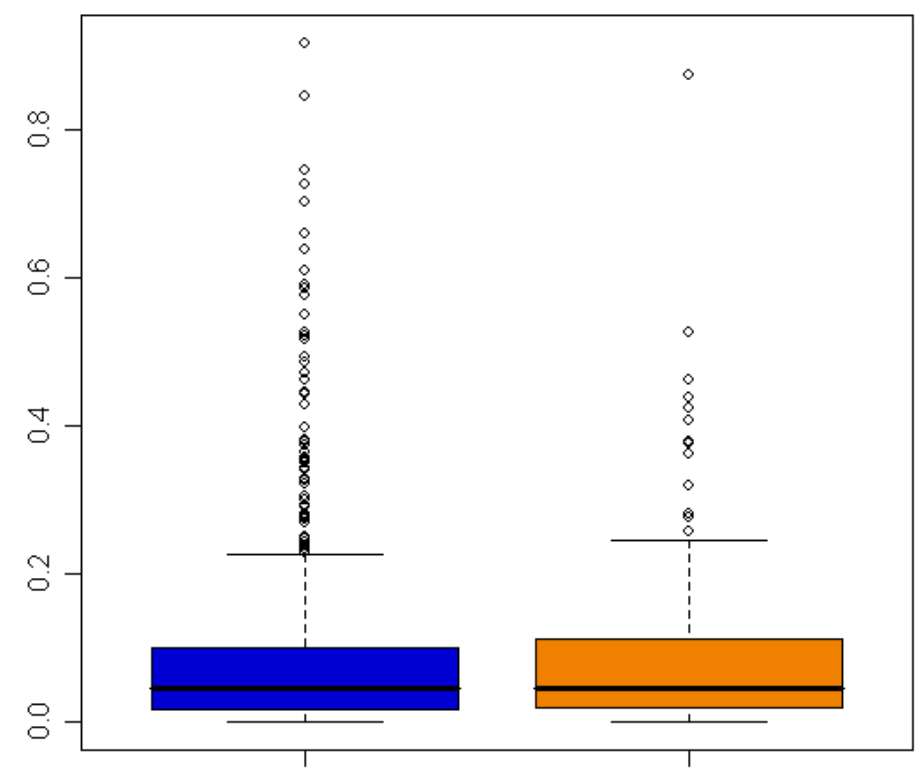

Auditor was not changed Auditor was changed

Figure 1. Earnings management of companies in periods when the auditor was and was not changed in the period from 1997 to 2007. 


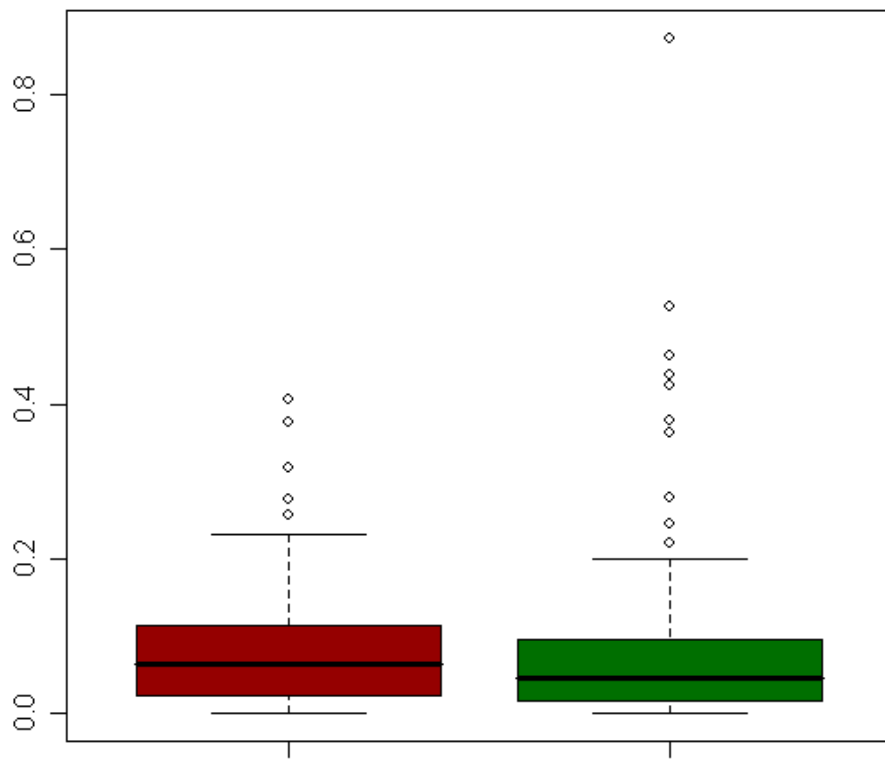

Obrigatory Rotation Spontaneous Decision

Figure 2. Earnings management of companies according to the reason for changing the auditor in the period from 1997 to 2007.

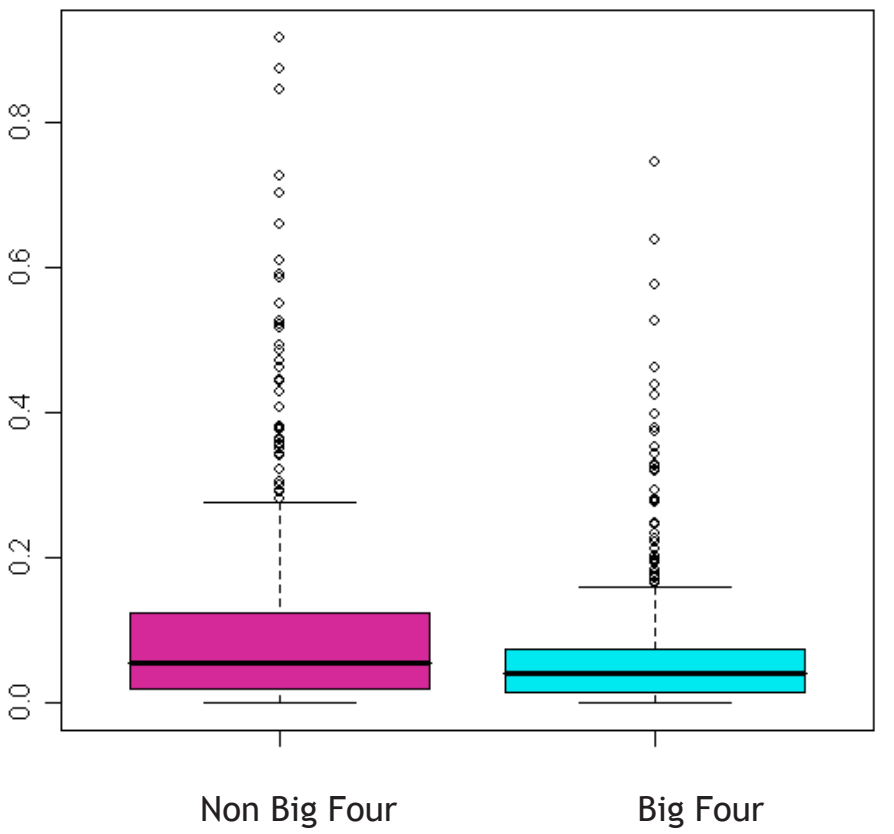

Figure 3. Earnings management of companies according to the classification of the independent auditor in the period from 1997 to 2007.

\section{MULTIVARIATE ANALYSIS - PANEL DATA}

We initially intended to perform the modeling with information on all the 
companies in the sample years. However, to facilitate the analysis of the model by balancing the sample, we decided to reduce it to include only companies with data available for the entire studied period (1997-2007). Besides, as mentioned above we also removed values that were extreme (excessively large). These values were in the interval $[1 ; 28]$ and their removal did not cause important changes in the predictors analyzed in the model. The final sample consisted of 868 observations. We separately analyzed in descriptive form some of the nine companies with extreme values.

The final regression for the panel has the following form:

$$
\begin{aligned}
& \text { Manage }_{i t}=0.0787-0.0122 \text { bigf }_{i t}+0.0109 R_{i t}-0.0028 \mathrm{Rs}_{i t}-0.0008 \text { Time }_{i t}- \\
& 0.00630 \text { pinion }_{\text {it }} \\
& \mathrm{i}=1, \ldots . .79 ; \mathrm{t}=1, \ldots ., 11 \text {. }
\end{aligned}
$$

where:

Manage $_{\mathrm{it}}$ : earnings management coefficient of company $\mathrm{i}$ in year $\mathrm{t}$;

Big4 $_{\text {it }}$ : a dummy variable that is 1 if the independent auditor of company $i$ in year $t$ was one of the Big Four, and 0 otherwise;

$\mathrm{Ro}_{\mathrm{it}}$ : a dummy variable that is 1 if company $\mathrm{i}$ changed auditors in ear $\mathrm{t}$ and this was caused by obligatory rotation, and 0 if the company either did not change auditors or did so spontaneously;

$\mathrm{Rs}_{\mathrm{it}}$ : a dummy variable that is 1 if company $\mathrm{i}$ changed auditors in year $\mathrm{t}$ spontaneously, and 0 if the company did not change auditors or had to because of mandatory rotation;

time $_{i t}$ : length of the auditor's relationship with company $i$ in year $t$, in consecutive years, based on the year of issuance of the auditor's opinion;

opinion $_{i t}$ : a dummy variable that is 1 if the auditor of company $i$ in year $t$ issued an opinion with reservation, and 0 if it issued an opinion without reservation.

According to this model, only the variable big4 was significant at $10 \%$ ( $p$-value $=0.078$ ), as shown in Table 4. Also, the average earnings management coefficient of the companies in 1997 was on average 0.0122 smaller when the auditor was one of the Big Four and the variables Ro, Rs and opinion were zero. In turn, the intercept of 0.0787 represents the earnings management expected in 1997 for companies when the variables big4, Ro, Rs and opinion were zero. Over the whole study period from 1997 to 2007, a spontaneous change in the auditor caused a decline of 0.0028 in the average earnings management coefficient. However, it increased on average when the auditor was changed because of obligatory rotation or when there was an opinion with reservation. On the other hand, the earnings management value declined on 
average 0.0008 for each increase of one year in the relationship between the auditor and client when the variables big4, Ro, Rs and opinion were zero.

Table 4 - Estimates of the parameters of the regression model by the method of Da Silva.

\begin{tabular}{cccccc}
\hline \hline $\begin{array}{c}\text { Variable } \\
\text { name }\end{array}$ & $\begin{array}{c}\text { Degrees } \\
\text { of } \\
\text { freedom }\end{array}$ & Estimate & $\begin{array}{c}\text { Standard } \\
\text { error of the } \\
\text { estimate }\end{array}$ & T-value & p-value \\
\hline Intercept & 1 & 0.0787 & 0.0090 & 8.72 & $<.0001$ \\
Big4 & 1 & -0.0122 & 0.0069 & -1.76 & 0.078 \\
Ro & 1 & 0.0109 & 0.0122 & 0.89 & 0.3721 \\
Re & 1 & -0.0028 & 0.0088 & -0.32 & 0.7497 \\
Time & 1 & -0.0008 & 0.0022 & -0.34 & 0.7374 \\
Opinion & 1 & 0.0063 & 0.0104 & 0.61 & 0.5434 \\
\hline \hline
\end{tabular}

\section{FINAL CONSIDERATIONS}

The main objective of this study was to investigate the relation between rotation of the independent auditor and the propensity of Brazilian public companies to manage earnings. For this purpose we analyzed a sample of non-financial companies with shares listed for trading on São Paulo Stock Exchange (BOVESPA) between 1997 and 2007, obtaining their financial information from Economática database and the name of the auditing firm from the website of Brazilian Securities Commission (CVM).

We first performed a descriptive and exploratory analysis of the data. For the empirical and statistical analysis, we used the abnormal working capital accruals (AWCA) method to measure the level of earnings management. We also formulated a mode with panel data due to the structure of the sample, which contained time series and cross-sectional data.

The descriptive and exploratory analyses suggested there is no association between earnings management and the following variables: reason for change of auditor (obligatory or spontaneous rotation) and type of opinion (with or without reservation). However, there was a relation between earnings management and type of auditing firm (one of the Big Four or not).

In the panel-data regression model, the average earnings management coefficient of the firms in 1997 declined by 0.0122 when the auditor was one of the Big Four, the opinions had no reservations and there were no changes in auditors. In turn, the intercept of 0.0787 represents the expected earnings management when the auditor that year was not one of the Big Four, the opinions had no reservations and there was not change of auditor. 
For the set of all companies over the entire study period, a spontaneous change of auditor caused a reduction of 0.0028 in the average earnings management value. However, earnings management increased on average when the auditor was change by mandatory rotation or when there was an opinion containing reservations. Furthermore, for each increase of one year in the relationship between the audit firm and client the earnings management coefficient decreased on average 0.0008 when the auditor was not one of the Big Four, the opinions had no reservations and there was not change of auditors.

The findings indicate there is no significant effect on earnings management of changing the auditing firm. It has been amply demonstrated elsewhere in the literature that companies audited by one of the Big Four are significantly less likely to manage earnings. A factor in this respect may be that all of the Big Four have internal policies to rotate the staff assigned to specific audited companies.

\section{REFERENCES}

ARENS, Alvin; ELDEE, Randal; BEASLEY, Mark. Auditing, an integrated approach, Pearson Education, 2002.

ASIC - Australian Securities \& Investments Commission. Auditors and Audit Committees - A Regulator's View. Available at www.asic.gov.au. May 2002. Accessed on: February 12, 2009.

ASSUNÇÃO, Juliano; CARRASCO, Vinícius. Avaliação da Rotatividade dos Auditores Independentes. Rio de Janeiro: Departamento de Economia da Pontifica Universidade Católica do Rio de Janeiro, 2008.

AZEVEDO, F. B.; COSTA, F. M. Efeito da troca da firma de auditoria no gerenciamento de resultados das companhias abertas brasileiras. In: II Congresso ANPCONT, 2008 Salvador. Anais. II Congresso ANPCONT, 2008.

BECKER, C. L.; DEFOND, M. L.; JIAMBALVO, J.; SUBRAMANYAM, K. The effect of audit quality on earnings management. Contemporary Accounting Research, v.15, Spring, p. 1-24, 1998.

BOYNTON, William C; JOHNSON, Raymond N.; KELL, Walter G. Auditoria. 7.ed. Translated by José Evaristo dos Santos. São Paulo: Atlas, 2002.

CHEW, N.G. Rotation of Auditors: History and recent developments. School of Accounting, Banking \& Finance. Logan Campus. Griffith University, Meadowbrook, Australia. Available at: http://www.unisi.it. Accessed on: August 13, 2009.

DA SILVA, J. G. C. The analysis of cross-sectional time series data. Dissertation (Ph.D. in Statistics), Department of Statistics, North Carolina State University, 1975. 
DAVIDSON, W; JIRANPORN, P.; DaDALT, P. Causes and Consequences of audit shooping: An analysis of auditor opinions, earnings management and auditor changes. Quartely Journal of Business and Economics, 45, pp,69-87, 2006.

DAVIS, L.R. ; SOO, B. ; TROMPTER, G. Auditor Tenure and the Ability to Meet or Beat Earnings Forecasts. Contemporary Accounting Journal, Vo. 26(2), pp. 517-74, 2009.

DAVIS, L.R. ; SOO, B. ; TROMPTER, G. Auditor Tenure, Auditor Independence and Earnings Management. Working papers series of Boston College, USA, 2000

DEANGELO, L. Auditor size and auditor quality. Journal of Accounting and Economics, v.3, p. 183-199, December 1981.

DECHOW, P.; SLOAN, R.; SWEENEY, A. Detecting earnings management. The Accounting Review, v. 70, p. 193-225, 1995.

DEFOND, M.; PARK, C. The reversal of abnormal accruals and the market valuation of earnings surprises. The Accounting Review, v. 76, n. 3, p. 375-404, 2001.

DeFONDS, M., SUBRAMANYAM, Auditor Changes and Discretionary Accruals. Journal of Accounting and Economics, 25, 1, pp. 35-67, 1998.

FAMA, Eugene F.; JENSEN, Michael C. Separation of Ownership and Control. Journal of Law and Economics. 1983.

FRANCIS, J.; MAYDEW, E.; Sparks, H. The role of Big 5 auditors in the credible reporting of accruals. Auditing: A Journal of Practice \& Theory, v. 18, Fall, p. 17-34, 2003.

GAO - United States General Accounting Office. Report to the Senate Committee on Banking, Housing, and Urban Affairs and the House Committee on Financial Services. Available at: www.gao.gov. Accessed on: July 10, 2008.

GEIGER, M. A.; and K. Raughumnamdam. Auditor tenure and audit reporting failures. Auditing: Journal of Practice and Theory. 2002.

JENSEN, Michael C.; MECKLING, William H. . Theory of the firm: managerial behavior, agency costs and ownership structure. Journal of Financial Economics. 1976.

JONES, J. J. Earnings management during import relief investigations. Journal of Accounting Research. Chicago, v. 29, n. 2, p. 193-228, Autumn 1991.

KANG, Sok-Hyon; SIVARAMAKRISHNAN, K. Issues in testing earnings management and an instrumental variable approach. Journal of Accounting Research. Chicago, v. 33, n. 2, p. 353-367, Autumn 1995.

NELSON, Mark W.; ELLIOTT, John A.; TARPLEY, Robin L. Evidence from auditors about managers' and auditors' earnings management decisions. The accounting review, v.77, 2002.

OLIVEIRA, Alexandre Queiroz de SANTOS, Neusa Maria Bastos Fernandes dos. Rodízio 
de Firmas de Auditoria: a experiência brasileira e as conclusões do mercado. Revista de Contabilidade e Finanças, São Paulo, v. 18, n. 45, pp. 91-100, September-December 2007

PAULO, E.. Manipulação das informações contábeis: uma análise teórica e empírica sobre os modelos operacionais de detecção de gerenciamento de resultados (in Portuguese). Tese (Doctoral Thesis in Accounting) - Programa de Pós-Graduação em Ciências Contábeis, Departamento de Contabilidade e Atuária, Faculdade de Economia, Administração e Contabilidade da Universidade de São Paulo., 2007

PIOT, C.; JANIN R., Audit Quality and Earnings Management in France. Working Paper, 2005, Available at SSRN: http://ssrn.com/abstract=830484

RAGHUNANDAN, K.; RAMA, D. V. SOX Section 4040 Material Weakness Disclosures and Audit Fees. Auditing: A Journal of Practice and Theory, v.25, n.. 1, pp. 99-114, May 2006.

SARBANES-OXLEY. Act of 2002. U.S. Congress, 2002. (Senate-H.R. 3763).

SEELY, J. Linear Spaces and Unbiased Estimation. Annals of Mathematical Statistics, v. 41, pp.1725-1734, 1970. 


\section{ENDEREÇO DOS AUTORES:}

\section{Antonio Lopo Martinez}

Fundação Instituto Capixaba de Pesq. em Contabilidade, Economia e Finanças. Av. Fernando Ferrari, 1358 -Boa Vista

Vitoria, ES - Brasil

29075-505

\section{Graciela Mendes Ribeiro Reis}

PricewaterhouseCoopers,

Rua Miguel Calmon no. 555 - 90. andar -Comércio

Salvador, BA - Brasil

40015-010 